\title{
Social representations of illness among people with chronic kidney disease
}

\author{
Representações sociais sobre o adoecimento de pessoas com doença renal crônica \\ Representaciones sociales de la enfermedad de las personas con enfermedad renal crónica
}

\author{
Caroline Gonçalves Pustiglione Campos ${ }^{\mathrm{a}}$ \\ Maria de Fátima Mantovani ${ }^{b}$ \\ Maria Elisa Brum do Nascimento ${ }^{c}$ \\ Cristiam Carla Cassi ${ }^{\mathrm{d}}$
}

\section{ABSTRACT}

Objective: To describe the social representations of illness among people with chronic kidney disease undergoing haemodialysis. Method: Descriptive, qualitative research, anchored on the social representations theory. This study was conducted in the municipality of Ponta Grossa, Paraná State, Brazil, with 23 adults with chronic kidney disease. Data were collection between February and November 2012 by means of a semi-structured interview, and analyzed using Content Analysis.

Results: The interviews led to the categories "the meaning of kidney disease": awareness of finitude, and "survival": the visible with chronic kidney disease. The representation of illness unveiled a difference and interruption in life projects, and haemodialysis meant loss of freedom, imprisonment and stigma.

Conclusion: Family ties and the individuals's social role are determining representations for healthcare.

Keywords: Renal insufficiency, chronic. Renal dialysis. Adult health.

\section{RESUMO}

Objetivo: Descrever as representações sociais de pessoas com doença renal crônica em hemodiálise sobre seu processo de adoecimento. Método: Pesquisa qualitativa, descritiva, ancorada na teoria da representação social. Realizada no município de Ponta Grossa (PR), envolveu 23 adultos com doença renal. A coleta ocorreu entre fevereiro e novembro de 2012, por meio de entrevista semiestruturada. Os dados foram analisados mediante o uso de análise de conteúdo categorial.

Resultados: Surgiu a categoria "significado do adoecimento renal": constatação da finitude; além da categoria "sobrevivência": 0 visível no adoecimento renal crônico. A representação de adoecimento revelou diferença e interrupção dos projetos de vida, e a hemodiálise significou perda de liberdade, prisão e estigma.

Conclusão: Considerou-se que os vínculos familiares e o papel social do indivíduo constroem representações determinantes para o cuidado. Palavras-chave: Insuficiência renal crônica. Diálise renal. Saúde do adulto.

\section{RESUMEN}

Objetivo: Describir las representaciones sociales de las personas con enfermedad renal crónica en la hemólisis sobre su proceso de enfermedad.

Método: Estudio cualitativo descriptivo, anclado en la teoría de la representación social. Realizada en la ciudad de Ponta Grossa (PR), abarcando 23 personas con enfermedad renal. La recogida de datos se realizó entre febrero y noviembre de 2012, a través de entrevistas semiestructuradas. Los datos fueron analizados utilizando el análisis de contenido categorial.

Resultados: Surgió la categoría el "significado de enfermedad renal": la realización de la finitud, más allá de la categoría: "supervivencia": Io visible en la enfermedad renal crónica. La representación de la enfermedad reveló una diferencia y la interrupción de los proyectos de vida, y la hemodiálisis significó la pérdida de la libertad, el encarcelamiento y el estigma.

Conclusión: Se considera que los vínculos familiares y el papel social del individuo en la sociedad construyendo representaciones determinantes para su cuidado.

Palabras clave: Insuficiencia renal crónica. Diálisis renal. Salud del adulto.
DOl: $\quad$ http://dx.doi.org/10.1590/1983-

1447.2015.02.48183 Ge Revista Gaúcha

\section{(147.2015.02.48183}

\footnotetext{
a Nurse. Master of Nursing Practice from the Universidade Federal do Paraná (UFPR). Professor of the Department of Nursing and Public Health of the Universidade Estadual de Ponta Grossa. Ponta Grossa - Paraná, Brazil.

${ }^{b}$ Nurse. Doctor of Nursing Practice. Associate Professor of the Department and Post Graduate Programme of Nursing of the UFPR. Coordinator of Scientific Initiation and Academic Integration of the UFPR. Scholarship student Productivity 2 CNPq. Member of the GEMSA. Curitiba - Paraná, Brazil.

' Nurse. Doctoral degree student of Nursing Practice at the Universidade Federal do Paraná (UFPR). Professor of the Nursing Programme of the Universidade Positivo. Member of the GEMSA. Curitiba - Paraná, Brazil.

${ }^{d}$ Nurse. Doctoral degree student of Health Sciences at the Pontifícia Católica do Paraná (PUC). Professor of the Department of Nursing of the UFPR. Curitiba Paraná, Brazil.
} 


\section{IINTRODUCTION}

People with chronic kidney disease (CKD) are immersed in a series of life changes that influence the way they think and act. In addition to the physical damage caused by kidney disease, patients suffer psychological pain and abrupt modifications to their daily lives $^{(1)}$. This series of problems tends to worsen in the final stages of this disease when patients must initiate haemodialysis.

Living with a chronic disease forces the suffers to centralize their activities around the illness and its treatment, since the haemodialysis that guarantees the adequate physiological conditions requires regular weekly sessions ${ }^{(2)}$. The resulting phenomenon causes concern and daily confrontations, which also lead sufferers to incorporate knowledge that assumes a dynamic form anchored on beliefs and perceptions.

These beliefs in relation to the disease help patients experience illness in a singular manner and consequently manage their care ${ }^{(3)}$. Furthermore, the experience of illness brings new encumbrances to kidney disease patients and the possibility to voice their judgement on how to cope and live with these problems.

A study on the representations of chronic kidney disease reveals the intensity of losses, suffering and anguish experienced by these patients, and highlights the significance of illness and the indivisibility between care practices and the psycho-affective and social relationships in their lives ${ }^{(4)}$. Social representations have also been useful for investigating the perceptions of care and adherence to treatment of haemodialysis patients ${ }^{(2)}$.

An understanding of the representational and consensual universe of people who experience the final stages of chronic kidney disease should help these patients express their needs and receive specific healthcare. This understanding allows them to define their desires, difficulties, attitudes and emotions in relation to the disease process. Knowledge of the representations of kidney disease and its influence on the various aspects of the elaborate and shared experience should support an understanding on how these people perceive the illness and how care and care practices to control this disease can become a part of their daily lives ${ }^{(2)}$.

The guiding question was: What are the social representations of people with chronic kidney disease on the illness process? To answer this question, the aim of this study is to describe the social representations of people with chronic kidney disease undergoing haemodialysis on the illness process.

\section{METHOD}

This is a descriptive study based on the qualitative approach, anchored on the Social Representations Theory (SRT) created by Serge Moscovici(5) that defines social representations as forms of practical knowledge by means of common sense. These representations establish an order that guides individuals in their social and material world, and enables the consequent communication among members of the same group ${ }^{(5)}$.

The Social Representations Theory addresses an object that is socially shared by a group and confers meaning to collective and individual experiences. It also articulates the practices and helps sustain the social identity of a group. Consequently, the SRT involves, as a criterion, the existence of an object or something that is being investigated, and the existence of a subject, something that represents the investigated object ${ }^{(5)}$. In the case of this study, the subjects are people with diagnosed chronic kidney disease and the object is the renal illness.

The study scenario was a healthcare organization, in the hospital and out-patient environment, that provides renal replacement therapy in the municipality of Ponta Grossa (PR). The organization is considered a benchmark in healthcare for chronic kidney disease among users of the Unified Health System (SUS), health plans and private patients. The patients who use the haemodialysis service also come from surrounding municipalities and regions.

Of the 100 patients with diagnosed chronic kidney disease, 23 were included in the study because they fully met the criterion of inclusion. These 23 patients were between the ages of 18 and 60 , both sexes, had been undergoing haemodialysis for more than one year, and were aware of their acts and eager to participate in the study. Those who did not meet the criterion for inclusion were excluded. The participants were selected with the help of healthcare professionals of the haemodialysis service.

Data were collected by means of individual semi-structured interviews recorded on an audio device at the nephrology service, in a private room, from February to November 2012. The duration of the interviews was between 20 and 30 minutes. The interview script was previously tested and recreated using closed questions related to participant characterization, such as age, sex, marital status, schooling, profession, and time of haemodialysis. The script also had open questions based on the discovery of the disease and emotions in relation to the diagnosis and the resulting life changes.

The interviews were transcribed and submitted to category content analysis in three stages: pre-analysis, analysis 
unit selection and categorization ${ }^{(6)}$. The interview scripts were then read repeatedly to better understand the content and identify the emerging meaning units. These units were organized, interpreted and analysed based on the respective statements that revealed the meaning and perception of the individuals who had chronic kidney disease and were undergoing haemodialysis.

In observance to the ethical and legal aspects of the National Health Council(7), the research project was submitted to the Ethics Committee of the Health Sciences Sector at the Universidade Federal do Paraná (UFPR), and approved under protocol CEP/SD no 1216.141.11.09. Prior to conducting the interviews, the script was presented to each subject, together with the objectives, method, risks and benefits of the study. The patients subsequently signed an informed consent statement to participate in the study. In order to respect the commitment of protecting the privacy of each participant, they were identified with the letter "P" and the order of the interviews, namely 1 to 23 .

This study was extracted from the master's dissertation, "The Social Representations (SR) of Chronic Kidney Disease" ${ }^{\prime \prime(8)}$.

\section{- RESULTS AND DISCUSSION}

A total of 16 women and 7 men with an average age of 40 participated in this study. The predominant age range was 41 to 50 years, corresponding to 8 participants. In terms of schooling, 1 participant was illiterate, 17 had finished primary school, 4 had finished secondary school and only 1 had a university degree. Of the participants, 11 were married or lived with a partner, 4 were separated/divorced and 8 were single.

In relation to profession/occupation, 8 were on sick pay, 5 had a remunerated activity and 5 were unemployed and did not receive any social security benefit, 4 were on permanent disability retirement and 1 was a home worker. In terms of time doing haemodialysis, there was a significant variation: the patient with the longest time had been doing haemodialysis for 25 years, and the patient with the least time had been doing haemodialysis for 1 year.

\section{The meaning of kidney disease: the awareness of finitude}

The discovery of the diagnosis was very particular and accompanied by representations that were anchored on the relationship of losses, consensually manifested by the participants, due to the insidious disease process. This caused insecurity and established new parameters of liv- ing by introducing a new reality with negative feelings and the image of suffering that is usually related to this disease, in addition to the despair, fear and approximation with death.

I was really scared of the diagnosis, I thought I would get better [...] I'm afraid of dying. (P22)

I really thought I would die, because I thought about the way people suffer when they do haemodialysis. (P14)

Kidney disease is thus characterized as being something unimaginable and feared, and as a condition that demands special treatment. It also represents a barrier in the living process that alters the lifestyle and the social role of sufferers. Based on the long-term impact of the disease on the patients' lives and normal daily activities, they also expressed concern, discomfort and sadness.

At this point, the ignored evokes fear because it threatens the sense of order and control over the world that is present in human subjectivity ${ }^{(5)}$. This is the reason people create the social representations of something that is familiar and therefore make the object less threatening. Normally, the problem can be overcome when it is integrated to the mental and physical world of these individuals, which makes this difficulty richer and possibly unequal. The unknown is formed by points of tension from the symbolic universe of a society and has the power to threaten the sense of order and control individuals have over themselves and their world ${ }^{(5)}$. This tension allows the construction of social representations that will establish an intermediation between the cognitive system of people and the social reality.

Additionally, the meaning of treatment implies the self-recognition of suffering and limitations, possibly determined by the previous knowledge of these participants, related to the invasive and permanent nature of haemodialysis. The suffering is greater when they receive the news of the loss of kidney function, as CKD starts off as a silent disease: the sufferers do not feel pain and continue urinating, which leads to the false impression that their kidneys are still functioning ${ }^{(9)}$.

The uncertainty in relation to the future, and the fear and panic will increase when people that have chronic kidney disease realize that they have definitively lost kidney function, which leads to abrupt changes, since Renal Replacement Therapy (haemodialysis) is immediate. At this point, the disease stops being imaginary, a possibility, and becomes a reality. The materialization of the death image associated to kidney disease projects a feeling of loss, at- 
tached to the memories of distance and rupture of the family ties.

I panicked, I couldn't stop thinking about my daughter. If I die, who I'm going to leave her with. (P7)

Concerns with the ruptured family ties expressed in this study, related to the possibility of death and the diagnosis of the disease, characterise a crushing reality in which these individuals review their relationships and responsibilities. The family is affected by the disease and may represent real fears that are proportional to the seriousness of the disease. The family must define strategies to cope with the impositions of chronic kidney disease ${ }^{(10)}$.

The family is a greater good that serves as a source of support and carries a substantial importance in the process of coping with the disease and its consequences, since it is part of the insertion context of these individuals. This is one of the aspects that has the greatest repercussions on the rupture of the rules of reciprocity. It somehow helps these patients to review the chronic status of their disease and influences the experience of the disease and the pursuit for coping mechanisms.

The interruption in the normal course of their lives incurs intense emotional reactions, such as "despair" marked by the shift in their social role. The serious impact caused by chronic kidney disease in their productive life and the difficulty of maintaining a home causes concerns that permeate these representations, indicating their potential deleterious effects on the emotional lives of these individuals.

I had to sell everything to pay for part of my treatment. Now I work to survive, I can't provide extra comfort for my family. (P9)

The fact that they are confronted with this situation interrupts the flow of their routines, which makes their experience with the disease more conflicting. In this case, these individuals tend to distance themselves from their own emotions, which are perceived as hostile and potentially destructive due to the burden of the psychological suffering.

I worked in the fields, helped my family, now I can't work anymore, I'm not strong enough. I lost my job, I lost my happiness. (P11)

The patients acknowledge and appreciate their jobs because they satisfy their survival needs and their realiza- tion, and because they performed activities that granted them pleasure and contentment. Another aspect related to employment is the fear of depending on their families or vice versa. When these patients provide for their families, the diagnosis causes anguish and suffering, which can extend their denial of the disease in order to flee from the situation.

This finding is similar to the results of a study conducted with a population of chronic renal patients, which showed that the restrictions in relation to work causes these individuals to lose their autonomy and financial independence. It also showed that, in some cases, the responsibility of supporting a family is transferred to another person, which also results in financial insecurity due to the loss of employment or an early retirement ${ }^{(11)}$.

Moreover, when these individuals find themselves in a stable clinical condition, they cannot get another job because they spend hours in dialysis therapy. Many of these patients, however, lose their primary source of income and have difficulty in financially supporting themselves and their families ${ }^{(12)}$. This can lead to individual consequences, such as a loss of self-worth due to the interrupted professional activities.

It is believed that the chronicity connected to people with chronic kidney disease, based on the treatment and loss of employment, leads to possible individual and collective changes of life, values, beliefs, habits and knowledge. This provides a culture that relates having chronic kidney disease with being closer to death; the culture of being the bearer of a social stigma and, therefore, marginalized and discredited ${ }^{(13)}$.

Analysis of the processes that form the social representations of chronic kidney disease showed that the awareness of finitude was associated to the prelude of death as a threat - in addition to losing a life, a family and a job. In fact, the representation of the renal disease process is perceived as being something bad and unpleasant, and as something that affects these people and incapacitates them; that reveals the difference and interrupts their projects of life.

\section{Survival: the visible in chronic kidney disease}

Chronic kidney disease was represented with the image of the "kidney that dries" and was associated to the perception of an initially silent trajectory with the awareness of chronicity. This idea is anchored on a concept that is still not fully understood by these individuals, and on an appreciation that is sometimes confusing, multifaceted, but determining. The term "kidney that dries" often consists in 
a resource that helps healthcare professionals communication the new condition and support the process of building a new identity after the diagnosis.

The doctor told me my kidneys were dry. The kidney disease started off really silently. (P4)

I'm not sure, I don't quite know how to put it, a kidney problem that has no cure. The kidney does not filter the blood, the kidney dries. (P13)

Withal, the perception of the disease as being silent was not consistent. For some of the patients, it was subordinated to the appearance and exacerbation of symptoms and complications, such as high blood pressure. For others, the change of living habits represented a visible and possible routine in relation to the disease, since even when they were faced with the limitations, they managed to incorporate the new condition and continue to live their lives.

I don't let the disease affect my life, but it does change a lot of things in my life and in the lives of my family members. (P5)

My life changed a lot [...] but I continue, there's no other way, I can't turn back the clock. (P11)

The meaning of renal chronicity was based on the image of the disease as a silent enemy, whose manifestations and the exacerbation of organic symptoms are tied to the regularity of haemodialysis. People that do haemodialysis need access to healthcare services to receive this treatment; they need strict dietary and medication control, and work-related restrictions that are directly connected to the context of disease and their personal, family and social lives (14). However, the need for treatment may interfere with their life plans in terms of time spent, and lead to symptoms like discouragement, tiredness and lack of energy ${ }^{(15)}$.

An understanding of the new routine, that is visible in light of renal disease, is associated to the presence of the machine as a guarantee of life. Elements that represent the disease, such as hope and tiredness, coexist with the duality in terms of the difficulties they have in accepting the treatment routine and their need to survive. This duality implies the aggregation between physical suffering (pain in the arm, mobility problems) and psychological pain (chronic kidney disease as something that is incurable).

It's tiring to depend on a machine to live, but I always come, I'm never absent because it's the only hope I have. (P1)
I don't like being here. Being connected to this machine makes me suffer, I can't move properly, my arm hurts. I only come to clean my blood and live longer, survive. I can't die now. (P5)

Here, death is very present in the expression "to survive". People also depend on family ties to find a reason to keep living their lives when confronted with renal chronicity. Consequently, the apprehension of the meanings of the machine, and the restriction and limitations with which they must now live, are gradually interwoven with the representations of loss of freedom, imprisonment and the stigma of the disease itself. The machine allows the maintenance of life. On the other hand, for some, it is a sign of difference due to the marks on their body.

The partnership of these individuals with the machine produces an ambiguity of emotions that can lead to the duality rage and gratitude, since they depend on the machine to maintain their lives ${ }^{(15)}$. The representation of loss of freedom and imprisonment refers to the stress they experience on a daily basis when they internalize the treatment in their lives and the impossibility of detaching from this treatment, since therapeutic failure would shorten their lives. The impact of this condition can lead people to other limitations in their social lives, such as leisure and travelling, in addition to changes in their body image.

Life changes, it's tough, because I liked to take trips, drive around, but now I'm stuck here and can't really leave. (P6)

I felt trapped, I can't go out anymore, I used to like going out, travelling, fishing, but I can't do that anymore, I just don't feel like it. (P10)

It's embarrassing because everyone stares. At first, I cried a lot, now I don't care anymore because I use long clothes. (P17)

[...] I don't like the fistula because it marks my body. I don't like it when people look and whisper. (P23)

The marks take on an even greater significance in the lives of these patients because they make them different to the rest of society, that is unaware of the characteristics of the disease. Depending on haemodialysis also has an impact on the lives of these patients. In addition to the perceptible physical changes that result from the disease, they must suffer the discomfort of the clinical condition and the routine of dialysis therapy. 
The procedures to create a point of access of dialysis, such as catheters and fistulas, produce a significant impact on the patients' body image, and they feel different to others and unattractive ${ }^{(16)}$. The visible alterations of the body of a chronic kidney disease sufferer caused by the treatment and the new condition lead to a permanent lifestyle transformation. In this case, the meaning of the body is intimately related to the construction of subjectivity, influenced by the social context and personal history.

Consequently, the representations that people with chronic kidney disease have in relation to these marks affect and guide the way they respond emotionally and behaviourally to these marks. This is especially important because it is believed that the experience of chronic kidney disease before and after dialysis determines their position in relation to the health-sickness process.

\section{-CONCLUSIONS}

It is considered that acknowledging oneself as a person that is experiencing chronic kidney disease, with haemodialysis, means to live with a negative role of losses and the explicit threat of death, in addition to subjecting oneself to the changes and necessary adaptations resulting from the disease. This fact affects the construction of singular social representations related to the meaning of being sick, which is associated to the constant and often painful transformations that vary according to the individuality and life changes of each patient.

The awareness of finitude represented, to the interviewed individuals, sadness, failure and interrupted life plans due to the interruption of their professional activities. Some of these patients also acknowledged and valued their jobs because they met their survival needs and involved activities that gave them pleasure and satisfaction.

The description of the social representations of chronic kidney disease suggests a multidimensional vision of the impact on the daily lives of these individuals. These elements emphasize the isolation and the stigma associated to the change of social role. From this perspective, this study remains open and future research is therefore important to re-evaluate the impact of these changes, especially in relation to the interaction between the individual experience and the social position. There is also a need to consider the broader context, since the investigation in question has limitations due to the application of interviews to adults only, which characterizes a type of representation that could be altered in studies among other age groups.
In addition to the high technology therapy provided for people with kidney disease, the representations that are based on family and social ties of these individuals should also be considered, since they are determining factors for the provision of care for this population.

\section{REFERENCES}

1. Braun L, Sood V, Hogue S, Lieberman B, Copley-Merriman C. High burden and unmet patient needs in chronic kidney disease. Int J Nephrol Renovasc [Internet]. 2012 [cited 2012 dez. 01];5:151-63. Available at: http://europepmc.org/ articles/PMC3534533

2. Chilcot J, Wellisted D, Farrington K. IIIness representations are associated with fluid nonadherence among hemodialysis patients. J Psychosom Res. 2010;68(2):203-12.

3. Goodman H, Firouzi A, Banya W, Lau-walker M, Cowie MR. IIIness perception, self-care behaviour and quality of life of heart failure patients: a longitudinal questionnaire survey. Int J Nurs Stud [Internet]. 2013 [cited 2013 jul. 04];50(7): 945-53. Available at: http://www.journalofnursingstudies.com/article/500207489(12)00408-7/fulltext

4. Lin CC, Chen MC, Hsieh HF, Chang SC. IIIness representations and coping processes of Taiwanese patients with early-stage chronic kidney disease. J Nurs Res [Internet]. 2013 [cited 2013 jan. 01]; 21(2):120-8. Available at: http://www. ncbi.nlm.nih.gov/pubmed/23681348

5. Moscovici S. Representações sociais: investigações em psicologia social. 8 ed. Petrópolis: Vozes; 2011.

6. Bardin L. Análise de conteúdo. Lisboa: Edições 70; 2011.

7. Ministério da Saúde (BR). Conselho Nacional de Saúde. Resolução no 196, de 10 de outubro de 1996. Diretrizes e normas regulamentadoras de pesquisas envolvendo seres humanos. Diário Oficial [da] República Federativa do Brasil. 1996 out.16;134(201 Seção 1):21082-5.

8. Gonçalves CS. As representações sociais sobre a doença renal crônica [dissertação]. Curitiba (PR), Curso de Enfermagem, Universidade Federal do Paraná; 2012.

9. Terra FS, Costa AMD, Ribeiro CCS, et al. 0 portador de insuficiência renal crônica e sua dependência ao tratamento hemodialítico: compreensão fenomenológica. Rev Bras Clin Med [Internet]. 2010 [cited 2010 aug. 02];8(4):306-10. Available at: http://files.bvs.br/ upload/S/1679-1010/2010/v8n4/a003.pdf

10. Schmitz J, Sandri JVA. A trajetória da família de portadores de insuficiência renal crônica: desafios e a emergência familiar. Nursing. 2011;13(154):138-43.

11. Patat CL, Stumm EMF, Kirchner RM, Guido LA, Barbosa DA. Análise da qualidade de vida de usuários em hemodiálise. Enferm Glob [Internet]. 2012 [cited 2012 jul. 01];11(3):66-76. Available at: http://scielo.isciii.es/pdf/eg/v11n27/pt_clinica4.pdf

12. Simpson CA, Silva FS. Trajetória de vida de transplantados renais: apreendendo as mudanças ocorridas na vida dos pacientes. Cienc Cuid Saude. 2013 jul/ set;12(3): 467-74.

13. Goffman E. Estigma: notas sobre a manipulação da identidade. 4. ed. Rio de Janeiro: LTC; 2008.

14. Mattos M, Maruyama SAT. A experiência de uma pessoa com doença renal crônica em hemodiálise. Rev Gaúcha de Enferm [Internet]. 2010 [cited 2011 mar. 04];31(3):428-34. Available at: http://www.scielo.br/pdf/rgenf/v31n3/ v31n3a04.pdf 
15. Coutinho NPS, Vasconcelos GM, Lopes MLH, Wadie WCA, Tavares MCH. Qualidade de vida de pacientes renais crônicos em hemodiálise. Pesqui Saúde [Internet]. 2010 [cited 2010 mar. 3];11(1):13-17. Available at: http://www.periodicoseletronicos.ufma.br/index.php/revistahuufma/article/view/328
16. Finnegan-John J, Thomes VJ. The psychosocial experience of patients with end-stage renal disease and its impact on quality of life: findings from a needs assessment to shape a service. ISRN Nephrol [Internet]. 2012 [cited 2013 oct. 21]:308986. Available at: http://www.ncbi.nlm.nih.gov/pmc/articles/PMC4045426/?report=reader

\section{Author's address:}

Maria Elisa Brum do Nascimento

Rua Comendador Macedo, 365/84, Centro

80060-030 Curitiba - PR

E-mail: melbrum.brum@gmail.com
Received: 27.06.2014

Approved: 28.04.2015 